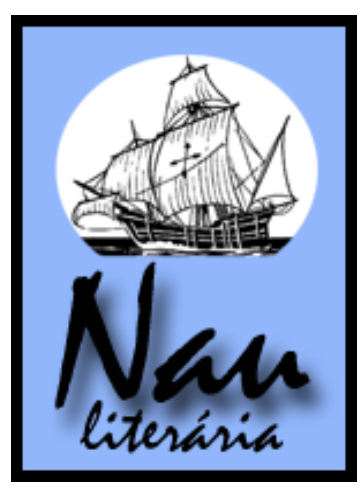

\title{
A cristalização do imaginário medieval na literatura de cordel
}

\section{Marcos Paulo Torres Pereira*}

\begin{abstract}
Resumo: O presente estudo tem como objetivo demonstrar a importância do imaginário, da memória e da identidade do povo nordestino brasileiro na produção poética da literatura de cordel, debatendo como substratos mentais que foram absorvidos através da hibridação cultural de sinais ibéricos do período do medievo europeu, especificamente no que se refere às manifestações cavaleirescas, foram recicladas e ressignificadas esteticamente através da cristalização na construção de um nordeste medieval.
\end{abstract}

Palavras-chave: Imaginário; mentalidade; medievalismo; literatura de cordel.

\begin{abstract}
The present study aims to demonstrate the importance of imaginary, memory and identity of the Brazilian northeastern people in poetic production of Cordel literature, debating how mental substrates that were absorbed through the Iberian cultural hybridization signals of European medieval period, specifically with respect to chivalric manifestations, and were recycled through the crystallization aesthetically resignified the construction of a medieval northeast.
\end{abstract}

Keywords: imaginary; mentality; medievalism; Cordel literature.

\section{$1 \mathrm{O}$ nordeste medieval}

\begin{abstract}
A parte desse Mundo que me fora dada - o Sertão - não era mais somente o "sertão" que tanta gente via, mas o Reino com o qual eu sonhava, cheio de cavalos e Cavaleiros de frutas vermelhas de Mandacarus reluzentes como estrelas, bicadas pelas flechas aurinegras dos Concrizes e respondendo às cintilações prateadas de outras estrelas... (Ariano Suassuna)
\end{abstract}

A heráldica é a ciência que estuda os brasões, insígnias ou distintivos de famílias nobres. Ciência que interpreta também ornatos e figuras dispostos no campo de um escudo ou fora dele, representando as armas de uma nação, um soberano, família, corporação ou cidade. Funcionalmente, servem os brasões não só como forma de distinção entre classes, entre diferentes, mas como modo de identificação e de pertencimento entre iguais. Simbolicamente, por serem conferidos, em regra, por merecimento, representam honra e glória.

Seguindo os ensinamentos de Ariano Suassuna apresentados no Manifesto Armorial (SUASSUNA, 1974), a alma dos brasões se cristalizou no nordeste brasileiro nos ferros de marcar gado: instrumentos utilizados por fazendeiros para registrar o pertencimento do animal ao rebanho e a seu dono. Assim como aqueles escudos europeus eram elaborados com

\footnotetext{
* Professor de Literaturas em Língua Portuguesa pela Universidade Federal do Amapá. Mestre em Letras pela Universidade Federal do Ceará; Especialista em Ensino da Literatura Brasileira. Atualmente desenvolve o projeto de pesquisa A invenção da nação: cristalização da ideia de Brasil nos cânones literários do modernismo, de 1922 a 1930.
} 
matizes significativos de ornamentos e figuras, o instrumento nordestino de ferrar segue regras de produção, tais como a da estilização de figuras, a da combinação de imagens (quando há a comunhão de famílias) e a hibridação do símbolo (quando a família começa a se repartir em ramos distintos). Quanto menos ornado o escudo, mais pura a linhagem.

Mesmo diferenciando o nordestino brasileiro do natural europeu no que tange à função, brasões e ferros de marcar representam um espírito de identidade.

O nordeste brasileiro, rico celeiro mestiço, converteu-se num "laboratório" da tradição e de suas constantes transformações, ganhando seu contorno mediante a colonização praticada no Brasil pela metrópole portuguesa, sob rígidos critérios de estratificação postos em prática na terra nova, à medida que a colonização se firmava no litoral, explorando o Pau-Brasil, a madeira em brasa, e demais riquezas naturais, processo que continuou com o envio dos bandeirantes do ouro, da prata e da esmeralda que abriram caminhos e fundaram cidades... Rasgando o sertão.

Nas palavras de Alfredo Bosi (1999, p. 15), define-se o caráter simbólico do ato de colonização de uma terra nova:

A colonização é um projeto totalizante cujas forças motrizes podem sempre buscar-se no nível do colo: ocupar um novo chão, explorar os seus bens, submeter os seus naturais. Mas os agentes desse processo não são apenas suportes físicos de operação econômica; são também crentes que trouxeram nas arcas da memória e da linguagem aqueles mortos que não devem morrer.

Esses “mortos que não devem morrer” aludidos por Bosi remetem aos sinais da cultura colonizadora que entram em contato com a cultura dos colonizados e se cristalizam, afinal o ato de colonizar estabelece não só as formas de exploração da terra nova, gerando uma nova mentalidade de feição única derivada dos elementos que a identificam, mas diferente por causa dos substratos surgidos na hibridação das duas culturas. Assim, o que era europeu passa a guardar semelhanças com o que é brasileiro.

Semelhanças são identificáveis, mas não igualdade, pois o que era vário de origem torna-se uno na identidade brasileira - que por si só é vária em relação às regiões e culturas que a formam. Nela, os substratos se cristalizam através do reconhecimento de que identidade é pertencimento.

Se o processo de criação e recriação de símbolos na transmissão do real e na representação artística se constitui na compreensão dos elementos formadores da mentalidade de um povo, então se pode definir a cultura desse povo como o resultado da soma dos resíduos de realidade: sedimentos que serão novamente materiais de criação simbólica, 
constituintes de um permanente ciclo de renovação, não apenas em conhecimentos reflexivos, mas mediante a imaginação criadora.

Esse processo de hibridação, espontâneo e autêntico, seguindo o rastro do contato entre a metrópole portuguesa e a colônia brasileira, delimitou as bases próprias do imaginário nordestino e da cultura nacional de forma abrangente. Nessa mentalidade em formação - pois o processo de hibridação e cristalização não cessa, é constante - repercute a singularidade de sua cultura popular exposta através das mais variadas manifestações surgidas na formação do povo.

Imaginário, conforme Hilário Franco Júnior (2003, p. 95-96), traduz-se como "tradução histórica e segmentada do intemporal e universal. Um sistema de imagens que exerce função catártica e construtora de identidade coletiva ao aflorar e historicizar sentimentos profundos do substrato psicológico de longuíssima duração".

O imaginário e, por extensão, a memória, são formadas por um fluxo ininterrupto e espontâneo de imagens que compõem o ideário e a mentalidade. Essas imagens requerem fundamentos e embasamentos para existirem, não surgem de um rompante, mas através das relações entre indivíduos, entre indivíduos e comunidades e entre as comunidades e os povos na tradição e no agora. Fustel de Coulanges (1961, p. 30-31) fixou em A cidade antiga:

Felizmente, o passado nunca morre por completo para o homem. O homem pode esquecê-lo, mas continua sempre a guardá-lo no seu íntimo, pois o seu estado em determinada época é produto e resumo de todas as épocas anteriores. Se ele descer à sua alma poderá encontrar e distinguir nela as diferentes épocas pelo que cada uma deixou gravada em si mesma.

O conceito de mentalidade que empregamos aqui se deve a Jacques Le Goff (1998, p. 72), que define o termo como aquilo que permanece na formação dos povos, envolta na história das estruturas mentais comuns a uma categoria social, a uma sociedade, a uma época: "a mentalidade é aquilo que muda mais lentamente". Desse modo, compreender o objeto de estudo da mentalidade é perceber que o coletivo é o norte a ser seguido, no seu caráter temporal e a-temporal, buscando entende-lo em sua estrutura, mediante heranças, continuidades, tradição, na reprodução mental das sociedades. Se, como afirma Franco Júnior (2003, p. 89), a mentalidade "é a instância que abarca a totalidade humana", então a mentalidade de um indivíduo histórico é justamente o que ele tem em comum com outros homens de seu tempo.

Quanto à relação do indivíduo com estas estruturas, cita Le Goff (1998, p. 71):

O nível da história das mentalidades é aquele do quotidiano e do automático, é o que escapa aos sujeitos particulares da história, porque revelador do conteúdo impessoal de seu 
pensamento, é o que César e o último soldado de suas legiões, São Luís e o camponês de seus domínios, Cristóvão Colombo e o marinheiro de suas caravelas têm em comum.

Esse conjunto de manifestações intelectuais e psíquicas que denominamos de mentalidade é representado na memória (por aquilo que vivemos e que, sem significados, pouco permanece, e por aquilo que é lembrado na saudade e que, por isso, não morre na distância do passado) pela ação da identidade. Não obstante, essa "forja" pela ação da mentalidade gera um sujeito universal, à proporção que as visões de mundo do coletivo são as que esse indivíduo acalenta na memória. Essas experiências passam a ser os caminhos das escolhas posteriores - agora pela ação do imaginário e da identidade - na tentativa de, se não recriá-las, viver situações que se assemelhem àquelas que foram importantes e ficaram na memória, pois o indivíduo se constrói na lembrança e se apaga no esquecimento.

Não há como negar o parentesco entre mentalidade e imaginário. Sobre a relação entre eles, Franco Júnior (2003, p. 95) assevera:

Acreditamos que imaginário não recobre as noções de mentalidade e de representação,
complementa-as, articula-se estreitamente com elas. Se a mentalidade é o complexo de
emoções e pensamento analógico (estruturas arcaicas sempre presentes no cérebro), imaginário
é a decodificação e representação cultural (portanto historicamente variável) daquele
complexo.

Partindo-se da premissa de que os cortes cronológicos da historiografia não correspondem às mudanças no universo mental, que se processam muito lentamente, percebemos que esses sinais de mentalidade redivivos nos sinais de identidade europeia podem ser percebidos nas mais diversas manifestações da identidade nordestina e brasileira, como nas quadrilhas juninas que remetem ao minueto francês, no picaresco João Grilo, nas bandas cabaçais e nos rabequeiros, no "amor cortês" do caboclo, nos lendários reinos encantados, nas narrativas populares, no Pedro Quengo do romanceiro, no mamulengo, nas quadrilhas, no léxico e nas expressões em uso no sertão, na religiosidade dos ex-votos (hoje, provas de graças alcançadas, ontem, troféus de guerra), nos jogos e jograis, no tom moralizante das narrativas populares, nas cavalhadas (resquícios das batalhas entre mouros e cristãos, que hoje se festejam em partidos azul e vermelho), nos aboios e no canto pungente dos repentistas, nos adágios populares... Cristais de formas simples.

Sinais de um medievo tardio que adquiriram novas expressões através da alma do nordestino tornam-se redivivos, dado o contato colonizador entre os povos durante o século ibérico, na criação e recriação de símbolos. 
Luis Soler (1978, p.74), versando sobre a mentalidade do nordeste brasileiro, estabelece razões da ausência do espírito da Renascença na mentalidade desse povo em formação, em virtude dos sinais de medievo remanescentes ainda no processo de colonização:

Tais considerações trazemos à baila para ilustrar, antecipadamente, o que nos parece ser a última chave que explica a ausência de qualquer influência renascentista nos grupos humanos que povoaram o sertão. (...) Efetivamente, aqueles grupos não foram recrutados entre as camadas que podiam estar mais ou menos impregnadas da mudança de civilização representada pela Renascença. Eram populações a nível de soldadesca, de camponeses e pequenos comerciantes, no melhor dos casos; de párias e buscadores de fortuna. Não fosse assim, aliás, o vasto sertão, duro e difícil, incompatível com naturezas frágeis, não os haveria de reter. (...) Por outra parte, na Corte lisboeta, o "espírito da Renascença” certamente, aparelhava naus, fornecia armas e recursos. Mas o que embarcou no outro lado do Atlântico para povoar o interior nordestino, foi ainda o "espírito medieval" com suas lendas, suas crendices e seus mitos, seus hábitos, sua tábua de valores humanos e morais, suas rústicas diversões e suas artes despretensiosas.

O "tronco ibérico" das raízes brasileiras (elementos que, a priori, seriam externos), em contato com o novo povo, torna-se híbrido na formação da mentalidade e da identidade da nova gente, afastando-se de sua origem, para formar um todo original. Desse modo, não se pode dizer que haja na identidade nordestina o medievalismo europeu, tampouco retorno a um passado medieval, que sequer se teve, mas recriação pautada numa mentalidade que se cristalizou formando um nordeste medieval.

O pensamento medieval não é uno, mas um complicado emaranhado significativo devido à grande gama de influências que recebeu o espírito do homem do período, proveniente da Igreja (principalmente), do senhorio feudal, das mudanças tecnológicas na agricultura e na indústria bélica, da invenção e crescimento das cidades e do contato com o mundo árabe durante as cruzadas - que trouxeram ao europeu novas tecnologias como o astrolábio (um dos instrumentos mais importantes das grandes navegações portuguesas), novos temperos e alimentos (como o limão e o cuscuz, por exemplo), novas estratégias militares, desenvolvimento do conhecimento empírico entre outros avanços culturais.

A propósito, posicionou-se Segismundo Spina (1997, p. 12):

O ingresso na cultura medieval, em especial a literária, não se faz sem pagarmos um pesado tributo; a compreensão dos valores dessa época exige do estudioso uma perspectiva ecumênica, pois as grandes criações do espírito medieval - na arte, na literatura, na filosofia - são frutos de uma coletividade que ultrapassa fronteiras nacionais.

Desse modo, o caminho que percorremos por esse bosque do espírito medieval, em essência, pode ser considerado também ecumênico à proporção que não nos ateremos a datas, mas a elementos desse imaginário na constituição de mentalidade nordestina medieval, representada neste artigo pela categorização do cavaleiro medieval e sua cristalização no sertão brasileiro através da literatura de cordel. 
No nordeste brasileiro, povo e natureza se oferecem à criação estética, pois, da paisagem, do ambiente social, da história, da herança cultural ibérica, dos dramas humanos, emana um castiço manancial simbólico, filtrado na identidade, iluminado pelo sol. Assim, os ferros de marcar gado se tornam sinais de identidade, delimitados na mentalidade da nova cultura que se formou da hibridação entre o europeu, o negro e o indígena.

\section{Cavaleiros do outrora: o ideal cavaleiresco do medievo}

Os romances de cavalaria se constituem o primeiro gênero literário de alcance continental nas línguas vernáculas emergentes.

No final da Idade Média, em uma sociedade que cultuava a figura do herói guerreiro como maior referencial de coragem, dever, virtudes e fé, torna-se o romance de cavalaria a prosa de ficção de maior sucesso de púbico, fazendo o agrado de homens e mulheres pela ação militar e pelo romance, respectivamente.

Provindas da Inglaterra e da França, as novelas de cavalaria têm origem nas canções de gesta, poemas medievais cantados, vazados em linguagem popular para celebrar feitos guerreiros. Segundo Spina (1997, p. 78-80), as novelas de cavalaria em literatura portuguesa, dependendo da origem de seus heróis, agrupam-se em três ciclos: Clássico (sobre temas latinos e gregos), o Carolíngeo (sobre Carlos Magno e os doze pares de França) e o Bretão ou Arturiano (sobre o rei Artur e os cavaleiros da Távola Redonda). Se formos além, no restante da Europa medieval encontraremos outros ciclos, como o de Guillaume d'Orange e o de Doon de Mayence, na França, e o de Mio Cid, na Espanha, sem esquecermos de Amadis de Gaula, naturalmente.

Coube à literatura o papel de enaltecer a imagem do herói medieval, ao criar a ilusão de que as virtudes viris dos cavaleiros andantes eram, por definição, a realização de um ideal de justiça, tanto na origem desse gênero no medievo, quanto no seu ressurgimento no início do século XIX, mediante o resgate temático do passado heróico dos países europeus no Romantismo, a fim de justificar o nacionalismo nessas nações através da figura do herói nacional representado pelo cavaleiro andante. Johan Huizinga (2013, p. 99) afirma:

Como ideal de vida bela, a concepção cavaleiresca tem aspectos peculiares. É um ideal essencialmente estético, feito de fantasias coloridas e sentimentos elevados, que também almeja ser um ideal estético: o pensamento medieval só pode conferir nobreza a um ideal de vida se o puder vincular à piedade e à virtude. Nessa sua função ética, o ideal cavaleiresco fica sempre a dever, estorvado por sua origem pecaminosa. Pois o cerne do ideal é sempre o orgulho elevado à condição de beleza. 
De forma nostálgica, esse resgate do medievo não se justificaria apenas pela recuperação histórica, quando um país era soberano e mais poderoso que os demais, mas pelo ressurgimento temático de valores e símbolos já tornados tradição desde o período clássico helênico, estes naturalmente cristalizados no imaginário popular durante a formação das nações.

No século XIX reeditaram-se diversos romances do período medieval, resgate temático que cria os alicerces alegóricos e imagéticos para em 1820 proporcionar o surgimento do romance histórico com Ivanhoé, de Sir Walter Scott.

Entretanto, o conceito de cavaleiro medieval, em sua origem, é diferente daquele que se construiu no imaginário coletivo e se tornou tradição. Enquanto a coragem e a bondade são os referenciais imagéticos tradicionais, a virilidade é o melhor atributo para se caracterizar o cavaleiro andante surgido em meados do século IX.

Le Goff (1985, p. 152) definiu: "conflito com o pai, conflito sobretudo com o irmão mais velho, herdeiro dos bens paternos. Muitos desses jovens são precisamente filhos mais novos, e essa situação contribui fortemente para o seu vaguear". Os cavaleiros pertenciam à nobreza, mas não tinham direito a sucessão de terras, pois apenas ao filho mais velho cabia tal direito. Esses guerreiros herdavam apenas os recursos necessários à aquisição de suas armas, além da dignidade que lhes conferia a possibilidade de sagrar-se um deles.

Armar-se e arcar com os custos das peças ofensivas e defensivas de armamento (capacete, escudo, armadura, lança), cavalo apropriado e escudeiro, era muito dispendioso. Portanto, só os nobres ou seus protegidos tinham condições de se dedicar à carreira das armas, a qual implicava em despesas que apenas uma minoria privilegiada poderia custear em seus próprios feudos, gerando o vaguear que os caracteriza.

As aventuras cavalheirescas eram marcadas por roubos, raptos e outras ações semelhantes em que a virilidade virtuosa figurava como tônica básica dos conflitos no contexto e condições dos feudos de sua origem. O conceito de "virilidade virtuosa" no período é também diferente do que ora temos. Escreveu Duby (1998, p.142):

\footnotetext{
Os valores que fundamentam a ideologia cavaleiresca, a exaltação da proeza, da rapina, da festa dos sentidos e da alegria de viver, evidentemente são construídos a partir de uma recusa resoluta do espírito de penitência e das renúncias pregadas e das renúncias pregadas pelos homens de oração.
}

A própria constituição do cavaleiro em armas e porte, tão simbólica hoje, atendia à necessidade de batalha, visto que os cristãos em combate com os árabes tinham muita dificuldade de enfrentar seus adversários, pois estes eram muito mais ágeis, unidos e 
numerosos. A cavalo, os guerreiros cristãos se fortificaram (puderam se proteger com mais eficiência utilizando escudos e armaduras de metal) e melhor atacar contando não apenas com o animal, mas com lanças e espadas mais pesadas. A espada, pesada e longa, talvez maior símbolo do cavaleiro, não contava em combate com a beleza da esgrima de um florim, mas com a rude violência do espancamento e não da estocada.

A guerra, e, por extensão, o combate, mais do que esforço para conquistar territórios, era uma busca de despojos.

A partir do século XI, segundo FRANCO JR. (2001, p. 22) a Igreja assumiu o controle sobre as investiduras da cavalaria, gerando grandes mudanças não apenas no cerimonial de sagração, mas, igualmente, no viver comum e no guerrear desses homens de armas, gerando novos signos de ética e fé. Desde então, nenhum cavaleiro recebeu armas sem antes assistir missa e passar uma noite de vigília e oração, na vigília das armas, para só então receber de um clérigo sua investidura simbolizada na espada, nas esporas, na cota de malha, no elmo, no escudo e na lança.

Nos séculos XII e XIII, a Igreja passou a estabelecer as normas de guerrear, proibindo ataque a mulheres, crianças, comerciantes, agricultores, padres, moinhos, igrejas, colheitas e animais domésticos, cuidou também de proibir a guerra durante a Quaresma, a Páscoa, Pentecostes e entre a noite de sexta-feira até a manhã da segunda, sob pena de excomunhão. Esses interditos muito contribuíram para instaurar uma atmosfera de paz social.

Durante as Cruzadas, um rígido código ético foi imposto a esses homens de armas, a fim de tirá-los da barbárie e elevá-los ao patamar do heroísmo. Essa ética se baseava em três grandes princípios: lealdade e fidelidade à palavra empenhada; generosidade, proteção e assistência aos necessitados; obediência à Igreja e defesa dos sacerdotes e de seus bens.

O meio no qual está inserido o herói serve para delimitar sua caracterização e suas ações, à proporção que este é criado pela mentalidade, preenchendo-o de matizes filtrados no imaginário e na identidade. Na ação de tessitura literária, estes matizes serão cristalizados, tornando-se tradição pelas histórias que serão propagadas a novas gerações. Reflexo de seu povo (anseios, identidade e memória), torna-se o herói um ideal a ser atingido.

Através da simbologia e do imaginário transmitidos pelo exemplo, a comunidade cria um código de conduta baseado nos costumes, o qual deverá ser seguido a fim de proporcionar os alicerces necessários à convivência comunitária. Esta simbologia, por si só, indica a consciência do coletivo através da qual se desenvolve a mentalidade: os elementos que identificam um povo se expressam através da memória, um dos elementos fundantes da mentalidade. 
As novelas de cavalaria surgem dessa realidade:

Como nos duelos os campeões estivessem armados de todas as peças, e como, com arma pesadas, ofensivas e defensivas, as de certa têmpera e de certa força representassem vantagens infinitas, a crença em armas encantadas de alguns combatentes deve ter transformado o juízo de muita gente. Disso nasceu o maravilhoso sistema de cavalaria. Todos os espíritos abriram-se para essas idéias. Viram-se, nos romances, paladinos, necromantes, fadas, cavalos alados ou dotados de inteligência, homens invisíveis ou invulneráveis, mágicos que se interessavam pelo nascimento e pela educação de grandes personagens, e ainda palácio encantados e desencantados; em nosso mundo, um mundo novo; e o curso da natureza deixado somente para os homens comuns. Paladinos sempre armados em uma parte do mundo cheia de castelos, de fortaleza e malfeitores, consideravam uma honra punir a injustiça e defender os fracos. Disso nasceu ainda, nos romances, a galanteria, fundada na idéia do amor ligada à de força e de proteção (MONTESQUIEU, 1979, p. 434).

É ao século XI que remonta a história de Rolando e seus pares. O Codex Calixtinus ou Líber Sancti Jacobi, bem exemplifica a associação imagética feita entre a Igreja e os cavaleiros medievais através da relação do imperador Carlos Magno com a Igreja de Compostela.

O Líber Sancti Jacobi relata a revelação feita por São Tiago a Calos Magno sobre o paradeiro do túmulo do apóstolo, e o caminho percorrido pelo guerreiro para a libertação da Galiza, para onde Tiago teria sido levado após seu martírio.

Escreveu Adeline Rucquoi (2007, p. 97):

O relato da revelação feita a Carlos Magno pelo apóstolo Tiago, que o incumbiu de libertar seu túmulo, e a campanha que se seguiu marcada pela tomada de Pamplona, pelo encontro com Ferragut e pelas lanças que floresceram antes da batalha remonta, sem dúvida, do [sic] século XI, época da primeira cruzada. Diante de uma Igreja gregoriana que questionava a apostolicidade da sé de Compostela, a atribuição da descoberta do túmulo ao grade imperador do Ocidente, coroado por um papa, e após uma campanha de liberação com todas as características de uma cruzada, vinha sem dúvida ao encontro da causa de Santiago.

Não obstante, tais fatos não se fazem perceber apenas nas histórias de Carlos Magno, pois a literatura do maravilhoso presente na matéria da Bretanha, por exemplo, ao narrar contatos humanos com o mundo sobrenatural retoma e funde a apocalíptica judaico-cristã aos relatos célticos. O ciclo arturiano é rico de narrativas heróicas, nas quais os ideais cavaleirescos são facilmente perceptíveis, pois agregam um conjunto de elementos da cultura tradicional e popular, como forma de estabelecer a identidade da média e da pequena aristocracia laica diante do clero.

Predominantemente heróico, feudal e guerreiro, o ciclo arturiano é composto pelas histórias de Tristão, de Percival (de Chrétien de Troyes), as do Romance do Santo Graal (de Robert de Borón), História do Santo Gaal, História de Merlin e A Morte do Rei Artur, além do livro de José de Arimatéia. 
O ciclo de Tristão é, talvez, um dos mais lembrados da literatura cortesã do medievo. Baseada numa lenda celta, a história narra os sucessos de Tristão que é encarregado por seu tio Marcos de procurar uma noiva digna de seu nome. Tristão encontra a linda princesa Isolda e com ela viaja de volta ao reino do tio. Entretanto, Tristão e Isolda bebem por engano uma poção mágica que estava destinada a despertar o amor entre esta e Marcos, gerando o conflito que norteará o desenvolvimento do ciclo. Neste rápido resumo, como nas demais obras da literatura cortesã do período, percebemos certa cristianização (idealização do amor, dama comparada à Virgem, amor carnal sublimado) dos símbolos emoldurados num amor erótico e contrário ao sacramento do matrimônio. Muito mais que sentimento, o amor se torna o próprio destino do homem.

A hibridação do imaginário cristão com o celta formou o ciclo arturiano, dando a este um aspecto que se destacou sobremaneira, à proporção que a lenda do Santo Graal, e de sua conseqüente demanda foram juntadas às aventuras dos lendários guerreiro da Távola. Sobre os símbolos místicos presentes nos romances de cavalaria escreveu Spina (1997, p. 62):

Ao maior representante da novela cortês, Chrétien de Troyes, devemos, em fins do século XII, a iniciativa de imprimir aos romances arturianos uma significação mística, compondo sua última obra, Percival. Os seus imitadores do século XIII deram seqüência a esse novo tipo de novela, criando o chamado ciclo místico do Graal; e na mesma época se opera uma renovação da forma, de capital importância para a história literária: o vasto conjunto Lancelot-Graal, constituído por volta do ano 1225 , utiliza a prosa pela primeira vez no gênero romanesco.

Le Goff (1994, p. 47) discorreu sobre o maravilhoso cristão:

Procurei, não digo definir - o que seria demasiado ambicioso -, mas delimitar um certo maravilhoso cristão, que é indubitável, mas que não representa no cristianismo algo de essencial e que me dá a impressão de, precisamente, se não ter formado porque havia essa presença e essa pressão de um maravilhoso anterior perante o qual o cristianismo devia pronunciar-se, tomar posição. O sobrenatural, o miraculoso, que são próprios do cristianismo, parecem-me de natureza e função diferentes das do maravilhoso mesmo tendo deixado a sua marca no maravilhoso cristão. Assim, o maravilhoso no cristianismo parece-me essencialmente encerrado nessas heranças - das quais encontramos elementos "maravilhosos" nas crenças, nos textos, na hagiografia. Na literatura, o maravilhoso é praticamente sempre de raízes pré-cristãs.

O Santo Graal é o cálice que teria sido utilizado por Jesus Cristo na última ceia e também servido para aparar seu sangue durante a crucificação. José de Arimatéia haveria ficado com a taça aos seus cuidados, para a posteriori entregá-la ao senhor do castelo de Corbenic. Há muito desaparecida, a taça reaparece em visão ocorrida na corte do Rei Artur, quando tem início sua busca. A demanda do Santo Graal narra a procura do sacro objeto, peleja na qual são enaltecidos o heroísmo e a pureza desses cavaleiros. Devemos ressaltar que a lenda reservava apenas aos puros de coração sua descoberta, e isso coube apenas a Percival, Galahad e Bors. 
Mesmo não fazendo parte do relato bíblico, ou de qualquer outro texto cristão antes do século XII, o Graal passou a ter grande importância no imaginário medieval, à proporção que alçou a elevados patamares o aspecto alegórico religioso mediante a eucaristia. A Igreja esforçou-se por valorizar este ritual, que antes era importante, mas sem grande destaque. Sendo apresentada de maneira quase teatral, a eucaristia insuflou nos cristãos os simbólicos “corpo e sangue de Cristo". Desse modo, o texto de Chrétien de Troyes, que marca a primeira aparição do mito que se tem notícia, veio também ao encontro dos ideais da Igreja, ajudando a aumentar o interesse dos cristãos pelo Graal. Surgido como resposta às crenças da Igreja, a demanda do Santo Graal floresceu no contexto das Cruzadas entre cavaleiros devotos.

Nos períodos de paz os cavaleiros podiam exercitar-se e se exibirem nas justas, torneios que tinham por objetivo resolver desavenças ou ainda ofensas à honra. A partir do século XII, as justas se convertem em verdadeiras festividades, realizando-se de cidade em cidade, em torneios com regras claras e pré-estabelecidas, vencendo as competições aquele que derrubasse o adversário da sua montaria. Atraindo multidões de espectadores e séquitos de nobres, além de pajens, tratadores de cavalos, escudeiros, armeiros e prostitutas, os embates passaram a ser realizados em feiras, figurando os protagonistas do combate como agitadores culturais e econômicos.

Por volta do século XIV, os torneios tornaram-se tão sofisticados que incluíam festas, bailes, banquetes e outras cerimônias, já distanciados de sua origem bélica e transformados em eventos sociais. O ideal cavaleiresco ainda perdurava, todavia não era mais o mesmo.

Se o desenvolvimento da metalurgia foi um dos responsáveis pelo surgimento dos cavaleiros medievais, à proporção que escudos e cotas de aço passaram a ser eficazes na defesa contra setas e flechas, inclusive as lançadas pelos arcos longos dos ingleses, foi o desenvolvimento da tecnologia militar que também decretou o seu fim: a pólvora usada em pistolas e canhões tornou mais fácil matar à distância. Era o fim do combate corpo a corpo dos cavaleiros, porém não o de símbolos e alegorias já tornados tradição no imaginário europeu e redivivos na mentalidade dos povos.

\section{Cavaleiros do sertão: cristalização do ideal cavaleiresco na literatura de cordel}

A literatura de cordel é uma importante manifestação da cultura do homem do Nordeste brasileiro. Nela temos um "jogo" imagístico no qual a arte e o homem se constroem em poesia popular. Através desta, o poeta, homem do povo, transcende a realidade, recriando o mundo à sua volta, que emerge como realização magnífica do que era comum. 
Legítimo documento de memória, seu surgimento está diretamente ligado à Europa, principalmente Portugal e Espanha, onde por volta do séc. XVII, popularizaram-se as folhas volantes ou folhas soltas em Portugal, vendidas por cegos nas feiras, ruas, praças ou em romarias, presas a um cordel ou barbante, para facilitar a exposição aos interessados, tal como ocorre ainda nas feiras do Nordeste, hábito que chegou até nós no século XVIII.

Gilmar de Carvalho (2006, p. 8), uma das maiores autoridades em literatura de cordel do Brasil, esclarece-nos sobre a origem dessa literatura popular:

\begin{abstract}
Existe uma lacuna entre a oralidade dos cantadores e o surgimento dos primeiros folhetos impressos. Este fosso se acentua dado o caráter precário do suporte que não resistiu ao tempo ou não foi objeto de estudo mais sistemático por parte dos pesquisadores do folclore ou dos teóricos da literatura. (...) Entre José de Alencar e Araripe Junior, que se debruçaram sobre a produção poética popular, e os primeiros exemplares constantes dos arquivos e coleções, existe um intervalo que instiga no sentido de que sejam procuradas pistas que ajudem a reconstituir a trajetória dos folhetos, numa cronologia que permita uma contextualização desta literatura e que diga de sua importância e permanência.
\end{abstract}

Para o povo nordestino, a literatura de cordel torna-se um dos principais meios de transmissão de valores, de mitos, da fantasia, de histórias e de sonhos indispensáveis à formação do imaginário que o singulariza relativamente ao restante do povo brasileiro, assumindo um caráter híbrido que se registra no plano popular (por ser feito pelo povo para o povo), no etnográfico (vide os valores, crenças e imagens), no da crônica poética (como bem atestam o ritmo e a musicalidade pungente de seus versos) e no registro histórico (durante muito tempo, o maior meio divulgador de informações no Nordeste brasileiro).

Quanto à importância da literatura de cordel, escreveu Mark Curran (2001, p. 19): "seus poemas de acontecimento são realmente memória, documento e registro de cem anos da história brasileira, recordados e reportados pelo cordelista que além de poeta é jornalista, conselheiro do povo e historiador popular, criando uma crônica de sua época".

A miséria do povo e os desastres climáticos (leia-se a seca e a "seca verde") são recriados na literatura de cordel através de símbolos, numa linguagem literária marcada principalmente pela hipérbole, uma constante no cordel, que caminha entre o drama e a poesia, entre a tragédia, a paródia e a sátira, quase sempre numa narrativa poética singular que reconstrói o mundo sob o olhar do homem comum, em clara representação do aspecto social, político, ideológico e cultural do nordestino.

Assim como ocorre com os demais povos, o povo nordestino utiliza os heróis e os mitos das tradições e do cordel para construir a sua vivência, atentando às escolhas que nortearam seu dia-a-dia. Quanto à singularidade do cancioneiro e do literário cordelístico, esclareceu Diégues Júnior (1981, p. 13): 
Uma das causas da singularidade do cancioneiro e do literário cordelístico nordestino brasileiro dá-se não só de fatores sociais, mas inclusive étnicos, como a assimilação mais estável do português e do africano escravo na área nordestina. Fatores esses que concorrem para que o nordeste fosse ambiente ideal à eclosão daquele tipo de literatura popular. Não apenas na literatura popular em versos - escrita, portanto -, mas igualmente na literatura oral, em versos, típica dos chamados cantadores de viola: repentistas e exímios cantadores de desafio - outra forma de poesia popular que recebemos da tradição ibérica.

Os folhetos de cordel, manuscritos ou impressos em Lisboa ou no Brasil circulavam no Nordeste, interiorizando a produção da literatura popular. No nordeste, enquanto não se difundia a tipografia, desenvolveu-se a literatura de cordel como forma de divulgar a poesia popular. Assim se constituiu o folheto da literatura popular, que passou a ser impressa em 8, 16 ou 32 páginas (dada a forma de editoração dos folhetos, ao fracionar uma folha por 4), encadernadas, com capas ilustradas com vinhetas, desenhos, fotografias e xilogravuras. Idelette Muzart-Fonseca dos Santos (2006, p. 59) assevera

A literatura de cordel, editada no Brasil desde a metade do século XIX, torna-se, nos primeiros anos do século XX, um sistema literário complexo e independente do sistema literário institucionalizado, com seus poetas, com suas casas editoriais pertencendo, via de regra, aos próprios poetas, com seus circuitos de distribuição e sobretudo com seu público, um público de iletrados, senão analfabetos, originariamente do mundo rural.

Conforme Roberto Pontes (1999, p. 47), o Brasil recebeu um repositório de sedimentos mais que representativos da literatura oral de extração geográfica e histórica originárias da Europa ibérica do final da Idade Média, que persistiram na poesia popular do Nordeste.

A ligação entre repente e cordel é deveras estreita na história da literatura popular nordestina, pois as narrativas das folhas soltas, sozinhas, não espalharam pelo sertão essa forma de narrar europeia. Coube também ao repente popularizar os temas e as histórias que vieram de além mar.

Graças ao ambiente marcadamente oral, os folhetos podem ser considerados um suporte de memória, pois conservam uma característica particular: são objetos de reunião e identificação, além de "objetos" culturais de retorno à mentalidade narrativa dos povos, retomada pela identidade do sertanejo, graças ao uso em sessões de leitura coletiva, pois a literatura de cordel não tem, em origem, o objetivo único de leitura individual e silenciosa.

A relação discursiva entre ambas as linguagens permanece, basta ver as marcas dialetais e de oralidade do cordel, além da significativa preocupação com o aspecto melódico de seus poemas.

Logo na introdução de Memória das vozes: cantoria, romanceiro \& cordel, vaticina Santos (2006, p. 15): 
Filósofos ou historiadores, pedagogos e pensadores, acordam-se em reconhecer que a memória não pertence ao passado, e sim ao presente. Reviver o passado ou descobrir sua significação, não significa encontrar ou recriar os fatos, as sensações ou as vozes tal qual foram vividos, ouvidos ou sentidos em algum momento do passado. Implica, pelo contrário, refazer, reconstruir e repensar as experiências do passado com as imagens, as palavras e as ideias de hoje. E não somente as nossas, individuais, íntimas, como também as coletivas, as que pertencem à família, ao gruo social ou ao país inteiro.

A ação de "refazer, reconstruir e repensar as experiências do passado com as imagens, as palavras e as ideias de hoje" não se traduz em reconstruir o passado, mas em revivificar os sinais, conscientes ou inconscientes, de identidade que matizam sua mentalidade. Assim, o romanceiro popular tradicional de origem europeia, na arte de poetas, nos cordelistas e nos costumes do povo sertanejo, cristaliza-se dado o enriquecimento das tradições populares e das formas elaboradas de literatura popular - leia-se literatura de cordel - e erudita.

Acerca da assimilação dos ideais do medievo pelos nordestinos, e quanto ao papel do herói nesta, explica Curran (2001, p. 61):

No cordel, o cangaceiro é o herói por excelência, misto de bandido, criminoso e lutador pela justiça no sertão nordestino. Nas obras cordelianas contemporâneas, é visto como o tipo heroico legítimo, maior do que a vida, verdadeiro "cavaleiro do sertão", com as cintas repletas de balas, o rifle "papo-amarelo" (winchester 44), o revólver e o facão. É conhecido pelos epítetos: Rei do Cangaço, Rei do Sertão, Terror do Nordeste, Rifle de Ouro, Leão do Norte, e no caso do célebre Lampião, Galo Cego. Trata-se da variante folclórica moderna do cavaleiro medieval, seguindo o modelo cordeliano extraído das histórias de Carlos Magno e seus pares, vê-se a cena de Carlos Magno chorando a morte de Rolando quando o cangaceiro AntonioSilvino chora a morte de seus homens depois de uma luta sangrenta, ou quando Riobaldo lamenta a perda de seus jagunços, na obra-prima de João Guimarães Rosa, Grande Sertão: Veredas.

Como elementos estruturantes de mentalidade, mediante sua ação na tradição, estão as Formas Simples, definidas por André Jolles (1976) como os traços de espírito de uma comunidade nas histórias e nas produções imateriais populares e folclóricas. Pertencem a este universo cristalizado as lendas, os mitos, as gestas, os provérbios, os casos, os contos, as memórias, os traços de espírito, as adivinhações, a música folclórica... É mediante a análise da cristalização de formas simples que poderemos compreender como os cavaleiros de outrora se viram ressignificados na literatura de cordel nordestina.

O conceito de cristalização devemos a Guerreiro Ramos (1939) que em Introdução à Cultura definiu o termo nos moldes que empregamos neste projeto. Segundo o sociólogo, cristalizar é recolher do imaginário e da mentalidade dos povos aquilo que é importante e que, por isso, tornou-se tradição.

A cristalização, como o recolhimento de substratos de tradição do imaginário e da mentalidade dos povos que serão reutilizados pela obra literária, constitui-se em re-elaboração 
constante das experiências vividas, memória e tradição, em um novo contexto imaginativo, que traz à obra novas possibilidades criativas que se tornarão responsáveis pela geração de um ato discursivo entre leitor e texto, mediante o processo de identificação de si e do outro, além de possibilitar ao plano enunciativo uma "abertura da significação" na qual se estabelecem relações novas entre os significantes e seu sentido, filtrados, de forma consciente ou inconsciente, pelos aspectos identitários que influenciam a mentalidade do povo no qual ele está inserido, gerando a permanência de sinas (étnicos, culturais, históricos, artísticos etc.), que serão novamente materiais de criação simbólica.

Cristalizar é retirar do comum e do tradicional, da memória do povo, sinais que serão redivivos na obra de arte acabada. Entretanto, esse registro não sentencia o final do exercício de cristalização, pois, no contato com a obra de arte, esse cristal adotará novos significados que passarão novamente a ser objeto de revivificação simbólica.

As Formas Simples nascem da disposição mental do povo em cristalizar o ser e/o acontecimento referencial num gesto verbal, através de propriedades específicas de querer dizer e significar. Estas surgem da necessidade de tornar o ser ou o fato analisado mais próximo de si e da comunidade na qual está inserido o indivíduo, transformando-se em marcador de identidade o substrato desta cristalização. Suzi Frankl Sperber (1997, p.99) assevera:

\begin{abstract}
Entendo as formas simples com o sentido apresentado por Andre Jolles: opções não abrangidas nem pela estilística, nem pela retórica, nem pela poética, ainda que possam ser utilizadas por todas elas. Encontram-se na oralidade e na escrita, mas provêm da oralidade. São pré-literárias, precedendo as manifestações realizadas historicamente na cultura literária e virtuais, podendo realizar-se ou não, escolhidas por autores conforme o seu código cultural literário, social e histórico. São blocos de sentido e forma encontráveis em variantes e sequências da ação relatada ficcional e historicamente. Correspondem a uma experiência pré-literária caracterizada fundamentalmente pelo esforço em atribuir um sentido global, de totalidade, a um fenômeno ou conjunto deles. Reúne eventos que tematizam a realidade interna e externa do ser humano, porém de modo a superar o limite do instante e do fragmento.
\end{abstract}

A ação das formas simples se perfaz em dois aspectos: o ideológico e o lingüístico. $\mathrm{O}$ indivíduo, na ação contínua da linguagem através da fala, transforma o fato e/ou o ser, empregando seu conhecimento linguístico e prévio de mundo, em conceito assimilado do ideológico para o linguístico. Entretanto, à medida que esses conceitos lingüísticos são cristalizados nas inter-relações sociais das comunidades, passam a fazer parte novamente do campo ideológico, servindo de substratos a novas formas simples e demais produções imateriais da comunidade.

Aqui cabe uma ressalva: formas literárias e formas cultas são termos homólogos que não perdem na escrita a tonalidade da fala, assim como seu espírito fundador, na construção 
significativa do enunciado (na origem da forma, apresenta caráter individual; no uso, entretanto, adquire aspecto social por ter sido aceita pelo grupo). Transpor para a obra literária não a forma dialetal normativa, mas os falares e o imaginário do povo, num "estilo que tivesse os bulbos mergulhados no húmus nativo" traz ao texto, através do registro e cristalização das formas simples, os substratos que identificam o leitor, tornando a transformação do texto em algo próximo, íntimo, pertencente por natureza à identidade do povo que o produziu: uma revivificação das coisas.

Essas dimensões passam a ser re-transformadas num processo de cristalização da mentalidade que, mesmo gerando um "sinal" novo, uma obra nova, ainda mantém vivo os resquícios de sua formação. Andre Jolles (1976, p. 38) define que

os elementos que decorrem de uma determinada disposição mental e da Forma que lhe corresponde só tem validade no interior dessa Forma. O universo de uma Forma Simples só é válido e coerente em seu próprio interior; desde que se lhe retire um elemento para transpô-lo a outro universo, tal elemento deixa de pertencer a uma esfera original e perde a validade.

Exemplos da ação de formas simples são encontradas através dos contos de Perrault, as Queixas de D. Urraca, Cid e o Mouro Dúcar (fragmento do romance castilhano Poema Del Mio Cid, do séc. XII), Gargântua (de estreitas ligações com o Calila e Dimna do Oriente), as novelas Carlos Magno ou Os quatro filhos de Aymon, O Homem Miséria (equivalente francês de Bernardo Cintura), e as novelas do Ciclo Arturiano, nos quais se evidenciam o amor cortês, os ideais cavaleirescos e a simbologia do herói, sinais que impregnam o imaginário medieval europeu e se recriam no imaginário medieval nordestino na constituição do herói cordelístico.

Roberto do Diabo é outro exemplo desses romances. Editado no Recife, em 1883, por João Martins de Athayde, a história chegou ao Nordeste através das tradições ibéricas em prosa para assumir a forma de folheto, assim como, ainda hoje, são reeditados em romances ou folhetos os grandes temas da novelística tradicional, como a Donzela Teodora, João de Calais, Carlos Magno e os Doze Pares de França, Pavão Misterioso. Câmara Cascudo coletou e estudou várias manifestações da mesma natureza, em livros como Vaqueiros $e$ Cantadores (1939), História da Imperatriz Porcina (1952), Cinco Livros do Povo (1953) e Flor de romance trágico (1966).

Em História de Juvenal e o Dragão, de Leandro Gomes de Barros, todos os elementos concernentes à construção mágica do herói são encontrados: I. O caminho de formação: de alguém comum, do povo, à condição de herói - desse modo servindo de modelo de conduta; II. A ação de animais mágicos: Rompe-Ferro, Ventania e Provedor, três cães que 
acompanham o herói em sua demanda, servindo-lhe de companhia e guarda (“os cães eram encantados / não podiam ter demora / se viraram em três pássaros / alvos de cor da aurora / disseram: adeus, Juvenal! /voaram e foram embora") e o dragão referido no título - ressalte-se que o dragão, no imaginário ocidental, representa a maldade; e III. A figura de uma nêmese: o cocheiro traidor representando o antagonismo de Juvenal não apenas na função, mas na constituição, pois, mesmo ambos sendo de origem humilde, as escolhas de um e de outro transformam um em herói, enquanto o outro é castigado: a vitória da virtude sobre a falsidade e a vilania.

Essa cristalização do símbolo (dragão) como referencial de maldade se encontra em outros cordéis, como João Valente e o dragão de 3 cabeças, de Joaquim Batista de Sena, da mesma forma como se figura na religiosidade do povo: o santo, São Jorge, enfrenta o dragão como representação da vitória do bem sobre o mal.

Assim como o cavaleiro medieval não podia ser caracterizado somente por sua virilidade, os cavaleiros do sertão, além de viris, caracterizam-se pelo temor e obediência à honra e à bondade e pela vassalagem amorosa dedicada a sua senhora.

Esse amor cortês, como característica do medievo, é encontrado na identidade nordestina através da idealização da mulher, representada, muitas vezes, como princesa, condessa, filha de fazendeiro etc. enaltecendo a diferença social/econômica entre estes.

No constante conflito entre o bem e o mal, e nos termos definidos pela Igreja, o espiritual representa o divino, enquanto o carnal se refere ao diabólico. O sexo era permitido no matrimônio apenas com fins reprodutivos, a virgindade era como uma virtude, enquanto o exercício da castidade foi amplamente amparado pela instituição.

Com o advento das cidades, e por influência da Igreja, na Idade Média registra-se grande mudança de mentalidade: uma naturalidade bruta comum à vida campesina foi abandonada em favor do sacramento do matrimônio, restringindo o sexo ao âmbito desse sacramento, assim a figura da mulher é envolta numa atmosfera sacralizante, como senhora (aspecto das cantigas de amor do trovadorismo), cristalizada nos cordéis Histórias da Princesa da Pedra Fina e Coco Verde e Melancia, de Leandro Gomes de Barros, Romance do Pavão Mysterioso, de João Melquíades Ferreira da Silva, História do Príncipe João Corajoso e a Princesa do Reino Não-Vai-Ninguém, de Joaquim Batista de Sena, e O Prêmio da Inocência, de Expedito Sebastião da Silva, por exemplo.

A paixão pela donzela justificaria qualquer demanda que tivesse por prêmio seu amor e riquezas, numa releitura temática cujas raízes residem no simbolismo do medievo europeu e nas tradições orientais apresentadas no Calila e Dimna e nas Mil e uma noites. 
A religiosidade do sertanejo se torna um representativo de mentalidade redivivo pela identidade medieval europeia, à medida que se constitui num pensamento "católico rural" que apresenta os santos sob aspectos humanos e próximos (coexistindo com a comunidade), mas também imbuídos do manto divino numa luta maniqueísta entre o bem e o mal.

Costumes ligados aos ingredientes místicos cristãos transcendentais e à magia e ao maravilhoso pagão da mentalidade medieval são constantes nas produções populares, vide os cordéis, A Profecia Misteriosa sobre os Três Dias de Estrondo, de São João de Cristo Rei, Luta e Vitória de São Cipriano Contra Adrião Mágico, de Joaquim Batista de Sena, A Chegada de Lampião no Inferno e O Grande Debate de Lampião com São Pedro, ambos de José Pacheco, A Mulher que Virou Bicho porque Profanou de Frei Damião, de Manoel Caboclo, como expositores desta mentalidade.

O medievo remanescente do sertanejo registra a singularidade da cultura popular exposta através das mais variadas manifestações surgidas na formação da cultura do povo, delineadas dia-a-dia no viver comum do homem e no viver transcendental do artista, na lírica de feição medieval que está cristalizada na memória popular do chamado "romanceiro" da literatura de cordel.

\section{Conclusão}

A cristalização da figura do cavaleiro andante como herói na literatura de cordel serve por corporificar a figura mítica do herói medieval como herói sertanejo, dada a permanência dessa forma simples no imaginário e na mentalidade do povo, ressignificando escolhas conscientes ou inconscientes que matizam o viver comum, que constroem tradições e que se apoderam de sedimentos de materiais de criação simbólica, trabalhados mediante a imaginação criadora, para movimentar permanente ciclo de renovação identitário. Sperber (2009, p. 369) afirma:

Enquanto fenômeno humano e cultural, o mito aparece no presente de cada indivíduo, já nas primeiras construções e manifestações, e também em cada comunidade e em cada cultura. Tem um presente sempre atualizado e um passado histórico. No presente tem uma dimensão psíquica, espiritual e social, que se soma à dimensão histórica, cultural e ancestral. Por sua atualização em cada existência humana, presta-se para as atualizações do tempo com o qual convive este sujeito. As estruturas míticas inatas juntamente com suas funções facilitam o encaixe de novos mitos criados com funções diferentes.

O cavaleiro medieval europeu não é o mesmo cavaleiro que encontramos no nordeste medieval brasileiro. Juvenal não é Arthur, o Carlos Magno daqui não é mais o Carlos Magno da França, os caminhos percorridos não são os mesmos, pois no vitral em que se instaura a mentalidade sertaneja, mesmo que se empreguem as mesmas cores da mentalidade européia, 
não formam a mesma figura, não formam uma cópia, mas uma nova imagem revista das cores que permaneceram no contato entre povos, a hibridação de culturas.

A literatura de cordel enaltece a imagem do herói cavaleiresco da mesma forma que as novelas de cavalaria enalteciam, tecendo a ilusão de que suas virtudes viris eram a realização de um ideal de justiça. Entretanto, na mentalidade de feição única do nordeste medieval, ressignificam-se sinais de um passado que o nordeste não vivenciou, porém o sentiu pelas narrativas heróicas que se espalharam das arcas da memória à formação da mentalidade, batilhando-se nos liames fronteiriços que identificariam esse povo.

As virtudes sertanejas do cavaleiro servem como pontos de identificação entre herói e povo, servindo como farol às virtudes que deve o povo seguir, relacionadas, principalmente, aos sinais de fé, à vassalagem amorosa na valorização da mulher e na força de se seguir os caminhos de retidão, expondo a permanência dos ideais de cavalaria na mentalidade sertaneja, mediante um "enraizamento" de ética e de moral cristã na cultura popular.

As sociedades têm sua mentalidade formada por símbolos e imagens, por matizes, sabores e aromas, por sons e sensações, por amavios e por encantatórios de linguagem que, mediante uma escolha valorativa (só se fica aquilo que se é importante), seja de forma consciente ou inconsciente, que se aproveitam da memória, da tradição e da cultura para o reconhecimento de si, como indivíduo e como comunidade, no texto literário.

O nordeste brasileiro apoderou-se de tradições, de sinais de memória e de identidade européia para o reconhecimento de si em escolha valorativas balizadas pela caracterização do herói cavaleiresco que identificam este povo através da égide de nordeste medieval.

\section{Referências}

BOSI, Alfredo. Dialética da colonização. $3^{\mathrm{a}}$ edição. São Paulo: Companhia das Letras, 1998.

CARVALHO, Gilmar de. Lyra Popular: o cordel de Juazeiro. Fortaleza: Museu do Ceará; Secretaria da Cultura do Estado do Ceara, 2006.

COULANGES, Fustel. A cidade antiga. São Paulo: EDAMERIS, 1961.

CURRAM, Mark. História do Brasil em cordel. $2^{\mathrm{a}}$ edição. EDUSP/Imprensa Oficial, São Paulo, 2001.

DIÉGUES JUNIOR, Manoel. Literatura de cordel. Col. Cadernos de Folclore. Rio de Janeiro. FUNARTE, 1981.

DUBY, Georges. "História social e ideologias das sociedades". In.: LE GOFF, Jacques \& NORA, Pierre. História: novos problemas. Rio de Janeiro: Francisco Alves, 1998. 
FRANCO JÚNIOR, Hilário. A Idade Média: nascimento do Ocidente. $2^{\mathrm{a}}$ ed. São Paulo: Brasiliense, 2001.

O fogo de Prometeu e o escudo de Perseu. Reflexões sobre mentalidade e imaginário. In.: Revista Signum, n. 05 - Revista da ABREM - Associação Brasileira de Estudos medievais. São Paulo: ABREM, 2003.

HUIZINGA, Johan. O outono da Idade Média.Trad. Francis Petra Janssen. São Paulo: Cosac Naiy, 2013.

JOLLES, André. Formas Simples. Trad. Álvaro Cabral. São Paulo: Cultrix, 1976.

LE GOFF, Jaques. Esboço de análise de um romance cortês. In.: $O$ maravilhoso $e o$ quotidiano no Ocidente medieval. Lisboa: Edições 70, 1985. . O imaginário medieval. Lisboa: Editorial Estampa, 1994.

. As mentalidades: uma história ambígua. In.: LE GOFF, Jaques. \& NORA, Pierry. História: novos objetos. Rio de Janeiro: Francisco Alves, 1998.

MONTESQUIEU. Do espírito das leis. São Paulo: Abril Cultural, 1979.

PONTES, Roberto. Poesia insubmissa afrobrasilusa. Rio de Janeiro - Fortaleza. Oficina do Autor/EUFC, 1999.

RAMOS, Guerreiro. Introdução à cultura. Salvador: Cruzada da Boa Imprensa, 1939.

RUCQUOI, Adeline. O caminho de Santiago: a criação de um intinerário. In. Signum. São Paulo. n. 9, 95-120, 2007.

SANTOS, Idelette Muzart-Fonseca dos. Memória das vozes: cantoria, romanceiro \& cordel. Salvador: Secretaria da Cultura e Turismo, Fundação Cultural do Estado da Bahia, 2006.

SOLER, Luis. As raízes árabes na tradição poético-musical do sertão nordestino. Recife: Editora Universitária/UFPE, 1978.

SPERBER, Suzi Frankl . Amor, medo e salvação. Aproximações entre Valdomiro Silveira e Guimarães. Revista do Instituto de Estudos Brasileiros. São Paulo, n.41, p. 97-120, 1997.

Ficção e Razão: uma retomada das formas simples. São Paulo: Aderaldo \& Rothschild: Fapesp, 2009.

SPINA, Segismundo. A cultura literária medieval. São Caetano do Sul. Ateliê Editorial, 1997.

SUASSUNA, Ariano. O Movimento Armorial. Recife, UFPE - Editora Universitária, 1974. 